\title{
Impact of Agrotechnical Factors on Maize Root System Development and Growth Stimulation of Indicator Microorganisms
}

\author{
Piotr Szulc $^{1 *}$, Katarzyna Ambroży-Deręgowska ${ }^{2}$, Iwona Mejza², Daria Szymanowska ${ }^{3}$, \\ Joanna Kobus-Cisowska ${ }^{4}$, Stanisław Grześ ${ }^{1}$ \\ ${ }^{1}$ Department of Agronomy, Poznań University of Life Sciences, Poznań, Poland \\ ${ }^{2}$ Department of Mathematical and Statistical Methods, Poznań University of Life Sciences, Poznań, Poland \\ ${ }^{3}$ Department of Biotechnology and Food Microbiology, Poznań University of Life Sciences, Poznań, Poland \\ ${ }^{4}$ Department of Gastronomical Sciences and Functional Foods, Poznań University of Life Sciences, Poznań, Poland
}

Received: 26 August 2019

Accepted: 29 January 2020

\begin{abstract}
Our study presents the results of field experiments whose aim was to assess the development of the root system of maize cultivars with different genetic profiles, depending on the method of soil preparation for sowing and NP fertilizer application. Laboratory tests included an assessment of the effect of mineral fertilizers used in field trials on selected groups of microorganisms that occur (or could potentially occur) in the soil environment. The "stay-green" cultivar was characterized by significantly higher indicators of soil overgrowth with roots in the $0-15 \mathrm{~cm}$ and $15-30 \mathrm{~cm}$ soil profiles than the classical cultivar. Row application of NP fertilizer stimulated the development of a maize root system in a $0-15 \mathrm{~cm}$ soil profile. The "stay-green" cultivar showed a positive reaction of root system development to row NP application. Model studies showed significant relationships associated with the chemical composition of mineral fertilizer or its dose and growth inhibition growth of microorganisms that could be part of the soil ecosystem.
\end{abstract}

Keywords: Zea mays L., fertilization, sowing, roots, antimicrobial activity, Tukey's HSD test

\section{Introduction}

Although root system development is genetically determined, it is subject to very strong modification by agrotechnical factors, e.g., fertilization method, soil cultivation or sowing method [1]. Root system

*e-mail: piotr.szulc@up.poznan.pl structure is strongly dependent on the state of soil compaction and the quantity of minerals distributed in the soil profile $[2,3]$. Changes in root system structure significantly affect the growth and development of the entire plant by modifying the ability to uptake water and nutrients dissolved in it. Root system structure depends on both the degree of soil compaction and the method of fertilization $[4,5]$. Changes in soil properties caused by its density (e.g., direct sowing) result in the destruction of root thickness and spatial distribution of their length, which in turn affects absorption capacity 
[6]. Additionally, local, increased doses of mineral fertilizers introduced into the soil as a result of the localized method (row application) contribute to changes in root morphology [7], affecting the uptake of water and minerals dissolved in it [2]. Agrotechnical factors, in addition to affecting root system development, strongly modify the microbiological life of the soil. The content of organic matter, nitrogen compounds, macroand micronutrients, water, oxygen, $\mathrm{pH}$, temperature, and the presence of pathogenic microorganisms [8] have a significant influence on the number and physiological and metabolic condition of microorganisms. Mineral fertilizers are one of the factors that may exert a significant inhibitory effect on soil microorganisms [9]. The aim of the field experiments was to determine the effect of the method of soil preparation for sowing and localized fertilization (row fertilization) on the indicator of soil overgrowth with roots in soil profiles of two types of maize cultivars. Laboratory tests comprised an assessment of the effect of mineral fertilizers applied in field trials on selected groups of microorganisms that are present (or could potentially be present) in the soil environment.

\section{Material and Methods}

\section{Experimental Field}

The field experiment was carried out at the Department of Agronomy of Poznań University of Life Sciences, on the fields of the Experimental and Educational Unit in Swadzim in the years 2013-2014. It was carried out over three years in the same scheme in a split-split-plot design with three factors and four field replicates. The study involved the following factors: A - $1^{\text {st }}$-order factor, two methods of maize sowing: A1-sowing to the soil (traditional cultivation), A2-direct sowing to the stubble after winter wheat (straw harvested); B - $2^{\text {nd }}$-order factor, two types of cultivars: B1-traditional cultivar SY Cooky, B2"stay-green" cultivar Drim; C $-3^{\text {rd }}$-order factor, 2 methods of supplying NP fertilizer: C1-distribution on the entire surface before seed sowing, C2-in rows simultaneously with seed sowing. The same level of mineral fertilization $\left(100 \mathrm{~kg} \mathrm{~N} / \mathrm{ha}, 70 \mathrm{~kg} \mathrm{P}_{2} \mathrm{O}_{5} / \mathrm{ha}\right.$ and $130 \mathrm{~kg} \mathrm{~K} 2 \mathrm{O} /$ ha) was applied on all experimental objects. Fertilization was balanced against phosphorus, which was applied at the whole required dose in the form of ammonium phosphate $\left(18 \% \mathrm{~N}, 46 \% \mathrm{P}_{2} \mathrm{O}_{5}\right)$. N and $\mathrm{K}$ fertilization was performed before maize sowing using urea $(46 \% \mathrm{~N})$ and potassium salt $(60 \%)$. Soil samples from $0-15 \mathrm{~cm}$ and $15-30 \mathrm{~cm}$ soil profiles with the maize root system were collected with a specialized drill bit with a volume of $250 \mathrm{~cm}^{3}$. After harvesting, maize roots were rinsed and weighed. Then, after drying, the obtained value was calculated per $g$ dry weight $/ 1 \mathrm{~cm}^{3}$ of the soil (the indicator of soil overgrowing with roots). Samples were taken between plants in a row.

\section{Weather Conditions}

Thermal and humidity conditions during plant vegetation in the years of the research were very diverse for maize growth and development. Influence of the thermal and humidity factor is comprehensively best depicted by the hydrothermal coefficient of water supply $[\mathrm{K}]$ according to Sielianinov. The optimal value of the coefficient is 1 . Values below 1 stand for drought, and those above 1 for a period of relative humidity (Fig. 1).

\section{Laboratory Tests}

In order to determine the antagonism of the tested fertilizers in relation to indicator microorganisms, experiments were carried out that included preparation of indicator microorganisms, preparation of fertilizers, and testing of antimicrobial activity using the well method.

\section{Preparation of Indicator Microorganisms}

The study investigated the effect of fertilizers on indicator microorganisms such as molds Fusarium sp., Aspergillus niger, Rhizopus sp., Penicillium sp., Alternaria sp., Trichoderma viride, and Torula herbanum and bacteria Escherichia coli, Clostridium butyricum, Bacillus subtillis, Azotobacter sp.,
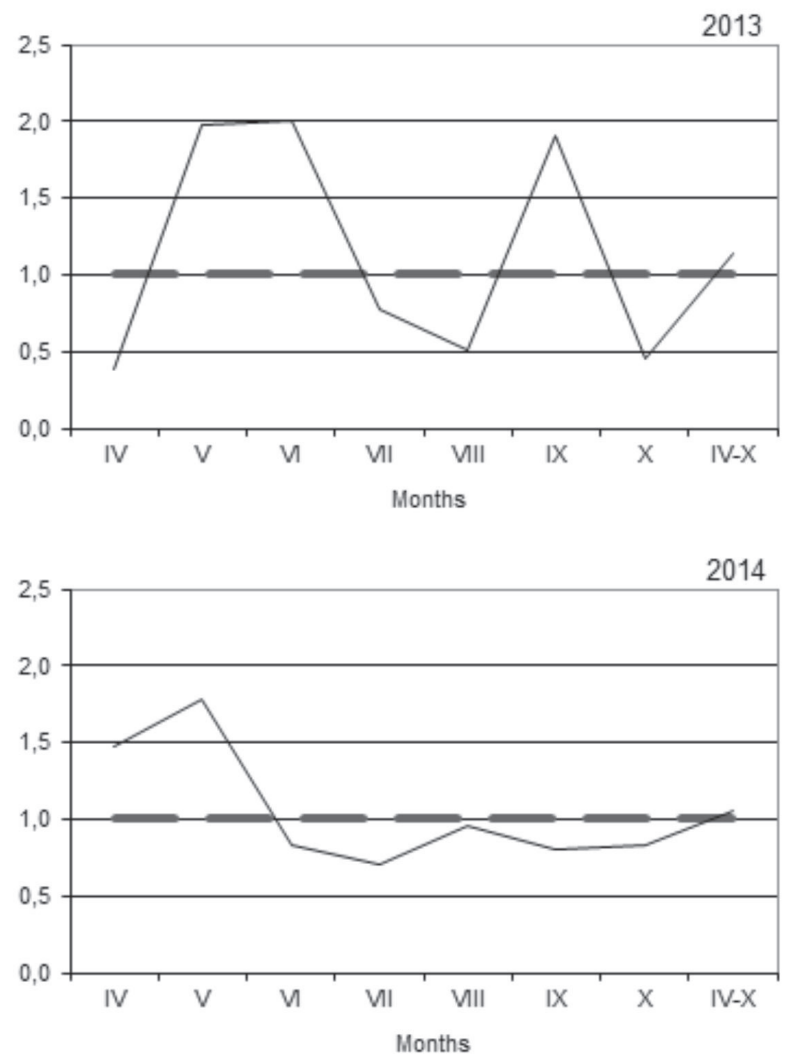

Fig. 1. Values of coefficient $(\mathrm{K})$ in vegetation periods of maize. 
Lactobacillus fermentum, Lactobacillus plantarum and Lactobacillus bulgaricus. In order to revive the microorganisms, the frozen sediments in glycerol stocks were transferred to tubes containing $10 \mathrm{ml}$ of broth medium with the addition of 2\% glucose. Culture conditions were adapted to the requirements of individual groups of microorganisms. The cultures were carried out at a $30^{\circ} \mathrm{C}$ (mold) or $37^{\circ} \mathrm{C}$ (bacteria) for 24 hours (bacteria) or 7 days (molds), in aerobic or anaerobic conditions. In the case of bacteria, pour plate procedure was applied by inoculating liquefied agar medium with $10 \%(\mathrm{v} / \mathrm{v})$ indicator culture. For molds, the top culture layer (spores) was collected and transferred to a solidified potato medium.

\section{Fertilizer Preparation}

Each of the three fertilizers (ammonium phosphate, urea, potassium salt) was prepared in four concentrations $(1,5,10$ and $20 \%) . \mathrm{NaCl}$ solution $(0.9 \%)$ was used as a solvent.

\section{Antimicrobial Activity Tests Using the Well Method}

Wells were made in the solidified medium using cork borer and fertilizer solution $(150 \mu \mathrm{l})$ applied to each well. Cultures were carried out in the conditions described in section 2.3.1. The diameters of the growth inhibition zone of indicator microorganisms were subsequently measured. Growth inhibition of the indicator microorganism, manifested by a complete clearing around the application site of fertilizer solution, indicated the cidal activity of the tested fertilizer. An increase in the density of the bacterial layer surrounding the well showed a stimulating effect in relation to the indicator applied. Two replications were made for each fertilizer, and the arithmetic mean was calculated based on the obtained results.

Table 1. Results of four-stratum (YABC) ANOVA for the observed traits.

\begin{tabular}{|c|c|c|c|}
\hline \multirow{3}{*}{ Source of variability } & \multirow{3}{*}{ Degrees of freedom } & \multicolumn{2}{|c|}{ Mean squares } \\
\hline & & \multicolumn{2}{|c|}{ The indicator of soil overgrowth with roots in the soil profiles } \\
\hline & & $0-15 \mathrm{~cm}$ & $15-30 \mathrm{~cm}$ \\
\hline Blocks & 1 & 0.00002 & 0.0003750 \\
\hline Years $(Y)$ & 1 & 0.00455 & 0.0001824 \\
\hline Error1 & 1 & 0.00161 & 0.0000521 \\
\hline Methods of sowing maize (A) & 1 & 0.02094 & 0.0001183 \\
\hline $\mathrm{Y} \times \mathrm{A}$ & 1 & 0.00009 & 0.0000556 \\
\hline Error 2 & 2 & 0.00139 & 0.0001348 \\
\hline Cultivars (B) & 1 & $0.01838^{* *}$ & $0.0009665^{* *}$ \\
\hline $\mathrm{Y} \times \mathrm{B}$ & 1 & 0.00150 & 0.0000085 \\
\hline $\mathrm{A} \times \mathrm{B}$ & 1 & 0.00089 & 0.0000028 \\
\hline $\mathrm{Y} \times \mathrm{A} \times \mathrm{B}$ & 1 & 0.00068 & 0.0000144 \\
\hline Error 3 & 4 & 0.00085 & 0.0000303 \\
\hline Methods of sowing NP fertilizer (C) & 1 & $0.06440 * *$ & 0.0002602 \\
\hline $\mathrm{Y} \times \mathrm{C}$ & 1 & $0.01645^{*}$ & 0.0000117 \\
\hline $\mathrm{A} \times \mathrm{C}$ & 1 & 0.00421 & 0.0000322 \\
\hline $\mathrm{B} \times \mathrm{C}$ & 1 & $0.01168^{*}$ & 0.0000004 \\
\hline $\mathrm{Y} \times \mathrm{A} \times \mathrm{C}$ & 1 & 0.00041 & 0.0000002 \\
\hline $\mathrm{Y} \times \mathrm{B} \times \mathrm{C}$ & 1 & 0.00024 & 0.0000389 \\
\hline $\mathrm{A} \times \mathrm{B} \times \mathrm{C}$ & 1 & 0.00145 & 0.0000853 \\
\hline $\mathrm{Y} \times \mathrm{A} \times \mathrm{B} \times \mathrm{C}$ & 1 & 0.00005 & 0.0000286 \\
\hline Error 4 & 8 & 0.00215 & 0.0000612 \\
\hline
\end{tabular}

** - significant at $p$-value $<0.01, *$ - significant at $p$-value $<0.05$ 
Table 2. Mean values of the traits for the years and other factors.

\begin{tabular}{|c|c|c|c|}
\hline \multirow[t]{2}{*}{ Factors } & \multirow[t]{2}{*}{$\begin{array}{l}\text { The levels of the } \\
\text { factors }\end{array}$} & \multicolumn{2}{|c|}{$\begin{array}{l}\text { The indicator of soil } \\
\text { overgrowth with roots in } \\
\text { the soil profiles } \\
\text { (g d.m. } / 100 \mathrm{~cm}^{3} \text { soil) }\end{array}$} \\
\hline & & $0-15 \mathrm{~cm}$ & $15-30 \mathrm{~cm}$ \\
\hline \multirow{2}{*}{ Y } & 2013 & $0.227^{\mathrm{a}}$ & $0.024^{\mathrm{a}}$ \\
\hline & 2014 & $0.204^{a}$ & $0.029^{\mathrm{a}}$ \\
\hline \multirow[b]{2}{*}{ A } & Direct sowing & $0.190^{\mathrm{a}}$ & $0.024^{\mathrm{a}}$ \\
\hline & $\begin{array}{l}\text { Sowing in the soil } \\
\text { cultivated in } \\
\text { traditional way }\end{array}$ & $0.241^{\mathrm{a}}$ & $0.028^{\mathrm{a}}$ \\
\hline \multirow{2}{*}{ B } & Traditional & $0.192^{\mathrm{b}}$ & $0.021^{\mathrm{b}}$ \\
\hline & "Stay-green" type & $0.240^{\mathrm{a}}$ & $0.032^{\mathrm{a}}$ \\
\hline \multirow{2}{*}{$\mathrm{C}$} & Broadcasting & $0.171^{\mathrm{b}}$ & $0.023^{\mathrm{a}}$ \\
\hline & In rows & $0.260^{\mathrm{a}}$ & $0.029^{\mathrm{a}}$ \\
\hline
\end{tabular}

$\mathrm{a}, \mathrm{b}$ - homogeneous groups $(\alpha=0.01)$

\section{Results}

\section{Field Experiments}

The obtained data were evaluated by analysis of variance (ANOVA) followed by Tukey's HSD test. Table 1 presents mean squares from four-stratum analysis of variance (ANOVA) for both traits $(0-15 \mathrm{~cm}$ and $15-30 \mathrm{~cm}$ profiles) given separately according to the split-split-plot model of data, with fixed effects of years (Y), methods of sowing maize (A), cultivars (B), methods of applying NP fertilizer (C), and interaction effects between them. Analysis of comparisons between the main effects of all factors and the years of the study shows significant differences between mean values of the indicators of soil overgrowth with roots in the $0-15 \mathrm{~cm}$ and $15-30 \mathrm{~cm}$ soil profiles for both cultivars (B), and between mean values for the methods of fertilization NP (C) only for the $0-15 \mathrm{~cm}$ profile over the study years. Table 2 shows that over the study years, the stay-green variety had significantly higher mean values of the indicator of soil overgrowth with roots than the traditional cultivar, in both soil profiles. Furthermore, the method of NP fertilizer application in rows led to a significantly higher mean value of the indicator of soil overgrowth with roots in the $0-15 \mathrm{~cm}$ soil profile than the broadcasting method, although in the $15-30 \mathrm{~cm}$ profile there were no significant differences between these mean values.

Table 1 shows no significant differences between mean values of the indicators of soil overgrowth with roots in both soil profiles in the years of the study and for both methods of sowing. However, for the $0-15 \mathrm{~cm}$ profile only, the analysis showed significant $(\mathrm{p}<0.05)$ interaction between the methods of NP fertilizer application and the years of study, and between the
Table 3. Mean values for the combinations of the years with other factors.

\begin{tabular}{|c|c|c|c|}
\hline \multirow[t]{2}{*}{$\begin{array}{l}\text { Years } \\
(Y)\end{array}$} & \multirow[t]{2}{*}{$\begin{array}{l}\text { Methods of sowing } \\
\text { maize (A) }\end{array}$} & \multicolumn{2}{|c|}{$\begin{array}{l}\text { The indicator of soil } \\
\text { overgrowth with roots in } \\
\text { the soil profiles } \\
\text { (g d.m. } / 100 \mathrm{~cm}^{3} \text { soil) }\end{array}$} \\
\hline & & $0-15 \mathrm{~cm}$ & $15-30 \mathrm{~cm}$ \\
\hline \multirow[b]{2}{*}{2013} & Direct sowing & $0.204^{\mathrm{a}}$ & $0.023^{\mathrm{a}}$ \\
\hline & $\begin{array}{c}\text { Sowing in the soil } \\
\text { cultivated in traditional } \\
\text { way }\end{array}$ & $0.251^{\mathrm{a}}$ & $0.025^{\mathrm{a}}$ \\
\hline \multirow[b]{2}{*}{2014} & Direct sowing & $0.176^{\mathrm{a}}$ & $0.025^{\mathrm{a}}$ \\
\hline & $\begin{array}{l}\text { Sowing in the soil culti- } \\
\text { vated in traditional way }\end{array}$ & $0.231^{\mathrm{a}}$ & $0.032^{\mathrm{a}}$ \\
\hline $\begin{array}{l}\text { Years } \\
(\mathrm{Y})\end{array}$ & $\begin{array}{l}\text { Cultivars } \\
\text { (B) }\end{array}$ & $0-15 \mathrm{~cm}$ & $15-30 \mathrm{~cm}$ \\
\hline \multirow{2}{*}{2013} & "Stay-green" type & $0.245^{\mathrm{a}}$ & $0.029^{\mathrm{a}}$ \\
\hline & Traditional & $0.210^{\mathrm{a}}$ & $0.019^{\mathrm{a}}$ \\
\hline \multirow{2}{*}{2014} & "Stay-green" type & $0.234^{\mathrm{a}}$ & $0.035^{\mathrm{a}}$ \\
\hline & Traditional & $0.173^{\mathrm{a}}$ & $0.023^{\mathrm{a}}$ \\
\hline $\begin{array}{l}\text { Years } \\
(\mathrm{Y})\end{array}$ & $\begin{array}{c}\text { Methods of sowing NP } \\
\text { fertilizer }(C)\end{array}$ & $0-15 \mathrm{~cm}$ & $15-30 \mathrm{~cm}$ \\
\hline \multirow{2}{*}{2013} & Broadcasting & $0.160^{\mathrm{b}}$ & $0.022^{\mathrm{a}}$ \\
\hline & In rows & $0.295^{\mathrm{a}}$ & $0.026^{\mathrm{a}}$ \\
\hline \multirow{2}{*}{2014} & Broadcasting & $0.181^{\mathrm{b}}$ & $0.025^{\mathrm{a}}$ \\
\hline & In rows & $0.226^{\mathrm{ab}}$ & $0.032^{\mathrm{a}}$ \\
\hline
\end{tabular}

$\mathrm{a}, \mathrm{b}$ - homogeneous groups $(\alpha=0.05)$

methods of NP fertilizer application and the varieties. Tukey's test showed that significantly the highest mean value of the indicator of soil overgrowth with roots in the $0-15 \mathrm{~cm}$ soil profile was obtained for application of NP fertilizer in rows in 2013 (Table 3). It is noteworthy that in the same year of study and for the

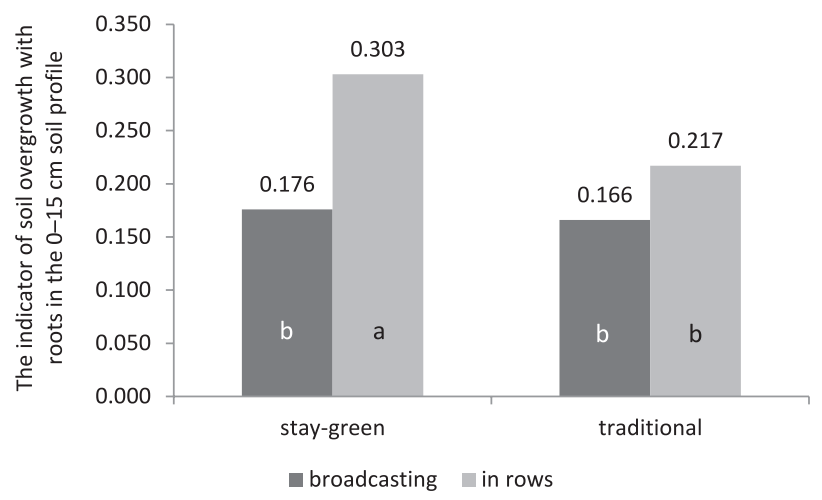

Fig. 2. Mean values of the indicator of soil overgrowth with roots ( $\mathrm{g} \mathrm{d.m.} / 100 \mathrm{~cm}^{3}$ soil) in the $0-15 \mathrm{~cm}$ soil profile for the combinations of two types of cultivars (B) and two methods of sowing NP fertilizer (C). a, b - homogeneous groups $(\alpha=0.05)$ 
same soil profile, the interaction between the methods of NP fertilizer application and the cultivars was also significant $(p<0.05)$. Fig. 2 shows that over the study years, the "stay-green" cultivar attained significantly the highest mean value of the indicator of soil overgrowth with roots in the $0-15 \mathrm{~cm}$ soil profile for application of NP fertilizer in rows.

\section{Laboratory Tests - Antimicrobial Activity}

The inhibitory effect of the fertilizer on microorganisms was demonstrated by growth inhibition zone manifested by a clear halo around the well containing the fertilizer at a certain concentration. The highest antimicrobial activity was demonstrated for ammonium phosphate, whose concentration was $20 \%$. In this case, $B$. subtillis growth inhibition zone was 32 $\mathrm{mm}$ (Table 4). In the case of potassium salt, the highest and the same values $(29 \mathrm{~mm})$ of the inhibition zone were demonstrated for molds of the genus Rhizopus sp., $L$. plantarum and E. coli. The weakest microbial growthinhibiting properties were demonstrated for urea. In this case, the largest inhibition zone was observed for L. bulgaricus $(22 \mathrm{~mm})$ and E. coli $(21 \mathrm{~mm})$ (Table 4).

\section{Discussion}

The basic function of the root system is to provide the right amount of water and nutrients necessary to obtain the yield at the expected level. In the conditions of no-till farming (direct sowing in stubble), the possibilities of impacting the soil environment and processes occurring in it are very limited. As a consequence, it can lead to a number of changes in root growth and development. Ball-Coelho et al. [10] found a clear influence of differentiated soil cultivation on the development of a plant's root system. In their study, they showed that under zero cultivation conditions, there was a change in the spatial distribution of the root system in the soil in relation to traditional cultivation. Maize roots developed much stronger in the upper layers of the soil profile and relatively weaker in deeper layers. Our own research confirmed the above statement. Bian et al. [11] showed that in a simplified system with direct sowing cultivation, the root volume density, ratio of shoot-to-root mass and root diameter were significantly lower than in traditional tillage objects. The statement cited above is consistent with the result obtained by [12], who in

Table 4. Effect of mineral fertilizers on indicator microorganisms (well-diffusion method).

\begin{tabular}{|c|c|c|c|c|c|c|c|c|c|c|c|c|}
\hline \multirow{4}{*}{ Indicator microorganisms } & \multicolumn{12}{|c|}{ Type of mineral fertilizer } \\
\hline & \multicolumn{4}{|c|}{ Urea $(46 \% \mathrm{~N})$} & \multicolumn{4}{|c|}{ Potassium salt $\left(60 \% \mathrm{~K}_{2} \mathrm{O}\right)$} & \multicolumn{4}{|c|}{$\begin{array}{l}\text { Ammonium phosphate }(18 \% \mathrm{~N} \text {, } \\
\left.46 \% \mathrm{P}_{2} \mathrm{O}_{5}\right)\end{array}$} \\
\hline & $1 \%$ & $5 \%$ & $10 \%$ & $20 \%$ & $1 \%$ & $5 \%$ & $10 \%$ & $20 \%$ & $1 \%$ & $5 \%$ & $10 \%$ & $20 \%$ \\
\hline & \multicolumn{12}{|c|}{ Inhibition zone [mm] } \\
\hline \multicolumn{13}{|c|}{ Fungi } \\
\hline Fusarium sp. & $\mathrm{NE}$ & $16 \pm 1.0$ & $13 \pm 1.0$ & $19 \pm 1.0$ & $\mathrm{NE}$ & $20 \pm 1.0$ & $16 \pm 1.0$ & $28 \pm 2.0$ & NE & $15 \pm 1.0$ & $26 \pm 1.0$ & $31 \pm 2.0$ \\
\hline Aspergillus sp. & $\mathrm{NE}$ & $12 \pm 1.0$ & $15 \pm 1.0$ & $19 \pm 1.0$ & $\mathrm{NE}$ & $21 \pm 1.0$ & $13 \pm 1.0$ & $26 \pm 2.0$ & $\mathrm{NE}$ & $14 \pm 1.0$ & $17 \pm 1.0$ & $21 \pm 1.0$ \\
\hline Rhizopus sp. & $\mathrm{NE}$ & $18 \pm 1.0$ & $12 \pm 1.0$ & $17 \pm 1.0$ & $5 \pm 0.0$ & $22 \pm 1.0$ & $16 \pm 1.0$ & $29 \pm 2.0$ & $\mathrm{NE}$ & $18 \pm 1.0$ & $6 \pm 0.0$ & $16 \pm 1.0$ \\
\hline Trichoderma viride & $\mathrm{NE}$ & $15 \pm 1.0$ & $12 \pm 1.0$ & $18 \pm 1.0$ & $\mathrm{NE}$ & $22 \pm 1.0$ & $12 \pm 1.0$ & $20 \pm 1.0$ & $\mathrm{NE}$ & $17 \pm 1.0$ & $18 \pm 1.0$ & $22 \pm 1.0$ \\
\hline Penicillium & $\mathrm{NE}$ & $17 \pm 1.0$ & $12 \pm 1.0$ & $18 \pm 1.0$ & $9 \pm 0.0$ & $20 \pm 1.0$ & $12 \pm 1.0$ & $25 \pm 2.0$ & NE & $15 \pm 1.0$ & $17 \pm 1.0$ & $27 \pm 2.0$ \\
\hline Alternaria & $\mathrm{NE}$ & $12 \pm 1.0$ & $12 \pm 1.0$ & $19 \pm 1.0$ & $\mathrm{NE}$ & $19 \pm 1.0$ & $12 \pm 1.0$ & $22 \pm 2.0$ & $\mathrm{NE}$ & $15 \pm 1.0$ & $16 \pm 1.0$ & $25 \pm 2.0$ \\
\hline Torula herbarum & $\mathrm{NE}$ & $15 \pm 1.0$ & $12 \pm 1.0$ & $16 \pm 1.0$ & $\mathrm{NE}$ & $17 \pm 1.0$ & $12 \pm 1.0$ & $21 \pm 1.0$ & $\mathrm{NE}$ & $16 \pm 1.0$ & $15 \pm 1.0$ & $19 \pm 1.0$ \\
\hline \multicolumn{13}{|c|}{ Lactic acid fermentation bacteria } \\
\hline Lactobacillus plantarum & $\mathrm{NE}$ & $12 \pm 1.0$ & $13 \pm 1.0$ & $19 \pm 1.0$ & $\mathrm{NE}$ & $21 \pm 1.0$ & $16 \pm 1.0$ & $29 \pm 1.0$ & $\mathrm{NE}$ & $17 \pm 1.0$ & $26 \pm 2.0$ & $31 \pm 2.0$ \\
\hline Lactobacillus fermentum & $\mathrm{NE}$ & $12 \pm 1.0$ & $15 \pm 1.0$ & $21 \pm 1.0$ & $\mathrm{NE}$ & $19 \pm 1.0$ & $13 \pm 1.0$ & $20 \pm 1.0$ & NE & $10 \pm 0.0$ & $17 \pm 1.0$ & $22 \pm 1.0$ \\
\hline Lactobacillus bulgaricus & $\mathrm{NE}$ & $15 \pm 1.0$ & $12 \pm 1.0$ & $22 \pm 1.0$ & $\mathrm{NE}$ & $29 \pm 1.0$ & $16 \pm 1.0$ & $22 \pm 1.0$ & NE & $18 \pm 1.0$ & $6 \pm 0.0$ & $14 \pm 1.0$ \\
\hline \multicolumn{13}{|c|}{ Bacteria potentially occurring in soil } \\
\hline Bacillus subtillis & $\mathrm{NE}$ & $29 \pm 2.0$ & $13 \pm 1.0$ & $19 \pm 1.0$ & $\mathrm{NE}$ & $19 \pm 1.0$ & $16 \pm 1.0$ & $27 \pm 2.0$ & NE & $19 \pm 1.0$ & $26 \pm 2.0$ & $32 \pm 2.0$ \\
\hline E.coli & $\mathrm{NE}$ & $18 \pm 1.0$ & $15 \pm 1.0$ & $21 \pm 1.0$ & $\mathrm{NE}$ & $20 \pm 1.0$ & $13 \pm 1.0$ & $29 \pm 2.0$ & $\mathrm{NE}$ & $29 \pm 2.0$ & $17 \pm 1.0$ & $22 \pm 1.0$ \\
\hline Clostridium butyricum & $\mathrm{NE}$ & $19 \pm 1.0$ & $12 \pm 1.0$ & $19 \pm 1.0$ & $\mathrm{NE}$ & $18 \pm 1.0$ & $16 \pm 1.0$ & $21 \pm 1.0$ & $\mathrm{NE}$ & $29 \pm 2.0$ & $16 \pm 1.0$ & $19 \pm 1.0$ \\
\hline Azoobacter & $\mathrm{NE}$ & $17 \pm 1.0$ & $12 \pm 1.0$ & $18 \pm 1.0$ & $\mathrm{NE}$ & $17 \pm 1.0$ & $12 \pm 1.0$ & $22 \pm 1.0$ & $\mathrm{NE}$ & $18 \pm 1.0$ & $18 \pm 1.0$ & $22 \pm 1.0$ \\
\hline
\end{tabular}

$\mathrm{NE}-$ no effect 
a study aimed at comparing soil cultivation systems also obtained significantly lower root system parameters in a simplified variant. In the present study, the indicator of soil overgrowth with roots was lower (only a trend) in maize planted directly in the stubble than in traditionally cultivated soil. In simplified cultivation systems, fertilizers are applied superficially, which results in a vertical variation in nutrient concentration in the soil layer penetrated by the plant root system [13]. Localized fertilization is definitely a better method for nutrient application in such conditions. The local, elevated dose of fertilizers introduced with the starter fertilization stimulated growth, contributing to the changes in root morphology and structure, affecting the uptake of water and minerals dissolved in it [6]. In field studies, Jing et al. [2] showed an increased growth of maize roots on objects fertilized locally with phosphor and nitrogen in an ammonium form compared to objects with nitrogen fertilization in the form of urea. Szulc et al. [7] also showed in pot experiments that point nitrogen application caused an increase in root diameter in the 4-5 leaf stage and root system length and surface in the 3-4 leaf stage compared to broadcast fertilizer application. The same study showed that point application of nitrogen in Fusarium Culmorum - inoculated plants contributed to the reduction of root system length in the 4-5 leaf stage and root surface in the 3-4 leaf stage in relation to uninfected plants, but fertilized in the same manner. The development of the root system in the present study was considerably affected by the type of maize hybrid. The Drim "stay-green" hybrid was characterized by a significantly better developed root system compared to the traditional cultivar SY Cooky. The obtained result has confirmed previous literature reports that "staygreen" cultivars are characterized by a stronger root system [14]. According to these authors, "stay-green" maize cultivar is characterized by a more dynamic root system development during juvenile stages compared to the traditional hybrid. The "stay-green" type of maize cultivar uptakes more efficiently nitrogen, phosphorus and magnesium from the soil during the grain-filling stage than the classical cultivar, which is possible thanks to the well-developed root system [15].

Microorganisms are one of the most important elements of the soil ecosystem. Moreover, there has been a trend for several years of supplying soil with microorganisms, for which the soil is not a natural living environment, such as inocula constituting a consortium of lactic acid bacteria [16]. Such treatments aim to stimulate metabolic activity of autochthonous soil microbiota as well as to provide valuable components resulting from bioprocesses, such as biotransformation or bioaccumulation. The inhibitory effect of tested fertilizers on microorganisms observed during experiments has confirmed the conclusion of many authors that soil fertilization improves its quality and enables higher yields; however, a high concentration of chemical compounds added endogenously to soil may disturb the qualitative and quantitative composition of its microbiota. It is also worth pointing out that microorganisms are involved in about $80-90 \%$ of all processes that occur in the soil; therefore, it is necessary to discover the influence of factors that determine their size and activity [16]. It is also worth noting that the processes occurring in the soil can produce toxic compounds that are the effect of changes taking place in this complex ecosystem, such as the formation of hydroxylamines and its derivatives, nitrites, nitrates or nitrosamines, which in turn are degradation products of more complex compounds. These compounds may have mutagenic or carcinogenic effects on soil microbiota and inhibit the activity of enzymes, mainly dehydrogenases [17]. The type of planting or its presence at all is also responsible for the proper microbiological condition of the soil (the highest number of microorganisms accumulates near the root systems) [18]. The conducted research has shown the inhibitory effect of fertilizers on indicator microorganisms, although the extent of the effect is determined by fertilizer composition, but primarily its dose. Compounds present in fertilizers are often components used in culture media (both industrial and laboratory) that are used by microbes as a source of nitrogen, phosphorus, potassium, magnesium, etc. Therefore, low concentrations of fertilizers should stimulate the growth of some microorganisms. Either no effect or inhibition of growth was found in the experiments carried out in this work. However, it should be noted that the in vitro experimental system does not reflect the complex soil ecosystem. This work investigated the direct effect of a given fertilizer on the reference species, but such a situation does not occur in a natural environment. Hower, the results of model studies showed significant relationships associated with mineral fertilizer composition or its dose, and growth inhibition of microorganisms that could be part of the soil ecosystem.

\section{Conclusions}

No significant effects of weather conditions in growing seasons and the method of soil preparation for sowing were found on the development of the mazie root system. The "stay-green" cultivar was characterized by significantly higher indicators of soil overgrowth with roots in the $0-15 \mathrm{~cm}$ and $15-30 \mathrm{~cm}$ soil profiles than the classical cultivar, regardless of years.

Row application of NP fertilizer stimulated maize root system development, increasing its indicator of soil overgrowth in the $0-15 \mathrm{~cm}$ soil profile. The difference between fertilization methods was $25 \%$.

The "stay-green" cultivar, fertilized in the row system, was characterized by a significantly higher indicator of soil overgrowth with roots $(39.6 \%)$ in the $0-15 \mathrm{~cm}$ soil profiles than the classical cultivar.

Model studies demonstrate significant relationships associated with the chemical composition of a 
mineral fertilizer or its dose and growth inhibition of microorganisms, a crucial part of the soil ecosystem.

\section{Conflict of Interest}

The authors declare no conflict of interest.

\section{References}

1. YAN H., LI K., DING H., LIAO C., LI X., YUAN L., LI C. Root morphological and proteomic responses to growth restriction in maize plantssupplied with sufficient $\mathrm{N}$. Journal of Plant Physiology, 168, 1067, 2011.

2. JING J.Y., ZHANG F.S., RENGEL Z., SHEN J.B. Localized fertilization with $\mathrm{P}$ plus $\mathrm{N}$ elicits an ammoniumdependent enhancement of maize root growth and nutrient uptake. Field Crop Research, 133, 176, 2012.

3. JONES B., LJUNG K. Subterranean space exploration, the development of root system architecture. Current Opinion in Plant Biology, 15, 97, 2012.

4. CAI H., MAB W., ZHANG X., PING J., YAN X., LIU J., YUAN J., WANG L., REN J. Effect of subsoil tillage depth on nutrient accumulation, root distribution and grain yield in spring maize. The Crop Journal, 2 (5), 297, 2014.

5. YU Z., PENG Y., YUN-FENG P., XUE-XIAN L., FAN-JUN C., CHUN-JIAN L. Fine root patterning and balanced inorganic phosphorus distribution in the soil indicate distinctive adaptation of maize plants to phosphorus deficiency. Pedosphere, 22 (6), 870, 2012.

6. ALMEDA D., VILLAR R. Linking root traits to plant physiology and growth in Fraxinus angustifolia Vahl. seedlings under soil compaction conditions. Environmental and Experimental Botany, 79, 49, 2012.

7. SZULC P., RYBUS-ZAJĄC M., WALIGÓRA H., SKRZYPCZAK W. Effect of Fusarium culmorum on the maize roots development in dependence from doses of nitrogen and the method of fertilization. Nauka Przyroda Technologie, 1, 1 \#1, 2007 [In Polish].
8. CECCANTI B., GREGO S. Influence of organic and mineral fertilisers on soil biological and physical properties. Bioresource Technology, 72, 9, 2000.

9. MiJANGOS I., PÉREZ R., ALBITU I., GARBISU C. Effects of fertilization and tillage on soil biological parameters. Enzyme and Microbiology Technology, 40, 100, 2006.

10. BALL-COELHO B.R., ROY R.C., SWANTON C.J. Tillage alters corn root distribution in coarse-textured soil. Soil and Tillage Research, 45, 237,1998.

11. BIAN D., JIA G., CAI I., MA Z., ENEJI A.E., CUI Y. Effects of tillage practices on root charakteristics and root lodging resistance of maize. Field Crops Research, 185, 89, 2016.

12. CHASSOT A., STAMP P., RICHNER W. Rot distribution and morphology of maize seedlings as affected by tillage and fertilizer placement. Plant and Soil, 231, 123, 2001.

13. OCHAL P., JADCZYSZYN T., JURGA B. Maize root development depending on the depth of fertilizer application to the Soil. Polish Journal of Agronomy, 23, 74, 2015 [In Polish].

14. SZULC P., BOCIANOWSKI J. Susceptibility of maize hybrids (Zea mays L.) to frit fly (Oscinella frit L.) under conditions of diversified nitrogen content in the soil and different types of nitrogen fertilizers. Acta Scientiarum Polonorum, Agricultura, 13 (2), 63, 2014.

15. SZULC P., BOCIANOWSKI J., RYBUS-ZAJĄC M. Accumulation of $\mathrm{N}, \mathrm{P}, \mathrm{K}$ and $\mathrm{Mg}$ nutrient elements and nutrient remobilization indices in the biomass of two contrasting maize (Zea mays L.) hybrids. Fresenius Environmental Bulletin, 21 (8), 2062, 2012.

16. TOMKOWIAK A., STARZYK J., KOSICKADZIECHCIAREK D., KARWATKA K. The influence of tillage systems on the microbiological condition of soil. Nauka Przyroda Technologie, 11, 4, 355, 2017 [In Polish].

17. ACOSTA-MARTINEZ V., TABATABAI M.A. Enzyme activities in a limed agricultural soil. Biology and Fertility od Soils, 31, 85, 2000.

18. HRYŃCZUK B., WEBER R. The influence of the mode of tillage on the intensity of microbiological changes in soil and the yielding of crops. Ann. UMCS, Sect. E, Agricultura, 59 (2), 639, 2004 [In Polish]. 